\title{
Decentralization of Authorities and Local Government Reform in Ukraine: Their Impact on the Efficiency of Public Law, Power and Strengthening of Democracy
}

\author{
Kofanova Nataliya
}

Expert of the Swiss-Ukrainian Decentralisation Support Project in Ukraine

(DESPRO), Merited Lawyer of Ukraine, Kiev, Ukraine

ORCID ID 0000-0003-1678-5247 kofanovanp@minregion.gov.ua

\section{Kofanov Andrii}

Legal Advisor to the Council of Europe Programme "Decentralization and Territorial Consolidation in Ukraine”, PhD of Juridical Sciences, Associate

Professor, Professor of Department of Forensic Support and Forensic

Expertise of the National Academy of Internal Affairs, Kiev, Ukraine

ORCID ID 0000-0002-5242-2518 kofanov_andrey@ukr.net

\section{Svoboda Eugenia}

PhD of Juridical Sciences, Associate Professor, Professor of Department of Forensic Support and Forensic Expertise of the National Academy of Internal Affairs, Kiev, Ukraine ORCID ID 0000-0002-8639-8333 jeechka@ukr.net

\section{Pavlovska Nataliia}

PhD of Juridical Sciences, Associate Professor, Professor of Department of Civil Law and Process of the National Academy of Internal Affairs, Kiev, Ukraine ORCID ID 0000-0003-3311-0364 wwwpav@gmail.com

\section{Romanenko Oleksii}

PhD in Law, Professor of the Department of Criminal Law of the

National Academy of Internal Affairs, Kyiv, Ukraine

ORCID ID 0000-0002-3553-4577 ovromanenko2017@gmail.com

\begin{abstract}
The decentralization of power in Ukraine, together with its impact on the efficiency of public authority and strengthening of democracy, is considered through a prism of theoretical concepts, dealing with the variety of types and major decentralization models, coupled with the corresponding advantages and risks.

Research Design \& Methods: The analysis covers the research and theoretical concepts, offering their own approach to decentralization by delegating certain public authorities to a lower level. It also considers the experience of other international countries to pass the decentralization process; the tools and risks that may be associated with the decentralization process; and the achievements and challenges of the decentralization process
\end{abstract}


in Ukraine. In the same time, the authors concentrate on substantiating the importance of balancing the national and local interests.

Contribution / Value Added: Although being theoretical, the article provides a foundation for a successful implementation of the decentralization process in Ukraine, which is a part of the most sectoral reforms.

Finding and recommendations: The authors believe that efficiency of public authority and strengthening of democracy in Ukraine shall depend on the ability of political elite to cooperate creatively and constructively for the further implementation of reforms under condition of the delineation of competences, functions, and responsibilities between the central, regional and local levels of government and territorial communities based on the new administrative and territorial division. It shall also depend on a greater political involvement among the primary holders of political power (citizens and community), which entails a greater understanding and support within a political elite and society. In case of Ukraine, the decentralization represents the imperative of our time and the foundation of the democratic governance model.

Keywords: decentralization, nation, democracy, local self-government, territorial community.

Introduction he attempts of launching liberal reforms in Ukraine were made from the very first days of independence. Though, the lack of political will to initiate a large-scale reform of public administration and territorial organization of power under conditions of decentralization and subsidiarity resulted in very little changes if any at all. Making the right choice for Ukraine and its further development regularly became the subject of heated discussions among scientists, public officials and the society. There was a need to reform the local government as a public institution and a part of the overall public administration system.

The decentralization of power plays an important role at the current stage of the development of Ukraine as a democratic state of law. This article is designed to uncover any challenges in developing legal foundations for the decentralization of public authority, its further implementation, and the role in strengthening the democracy and preserving the system of the people's authority within a country.

Analysis of recent studies and publications According to national and international scientific and practical researches, the implementation of a decentralized governance (hereinafter referred to as the "Decentralization") is considered as a multifaceted concept that represents, in the most general terms, the transfer of authority (power), responsibility and resources from a national (state) to a subnational (regional, local) level, which is represented with the corresponding government agencies, to local agencies (regional offices) of central executive authorities, or to a private sector (Nyzhnyk, 2016, Averianov, 1998, Varnalii, 2007, Nyzhnyk, 1997, Odintsova, Mostovyi, \& Amosov, 2002).

There are different approaches to axiology behind the decentralization of public authority, government authority, executive authority, and public administration as well as its definition, typology and classification depending on the research subject. 
According to the Encyclopedia of Public Administration, the decentralization is defined as the mechanism for territorial organization of power, which is used by the state to delegate the decision-making authority in certain areas or matters to local or regional agencies that are not part of the executive authority and retain a degree of independence. It is a complex notion in a democratic state of law, which provides for the delegation of certain power by the central state administration authorities to some lower level agencies with corresponding rights, responsibilities and resources. The ultimate purpose for such a redistribution of power would be the ability to take management decisions at the national, regional and local levels. [19].

The decentralization is designed "to increase the efficiency of State machinery and promote the development of regional agencies and municipality based on the principles of democracy, which could be measured by full enjoyment of all human rights, legitimate interests and responsibilities of local population in the form of municipal, community or regional teams territorial self-governing bodies" [4].

There are various views on the types of decentralization. Z. Varnaliy and M. Kornienko distinguish two types of decentralization: the deconcentration and the devolution. The deconcentration - is the delegation of certain authorities to the respective regional representative, while preserving significant influence of the supreme governing body in case of the centralized state. The devolution entitles self-government authorities with the right to take decisions and pursue an independent financial and management activity. In case of devolution, the local self-government authorities acquire a legally independent status, turning themselves into a separate administrative level, where the government maintains only an indirect control.

The main objective of the decentralization process under present conditions is the clear delineation of competences, functions, and responsibilities between the central, regional and local levels of government [7, 26, 27].

Referring to studies made by the Manor J. (1999), O. Kuchynskyi distinguishes three major types of decentralization. He believes devolution to be the only democratic method as it provides for a significant transfer of authority and resources to the local government level. It is the type that is currently implemented in Ukraine. The other two types - the deconcentration and the delegation - only provide for the transfer of authority from a higher to a lower level of 
government, while the local government is only entitled to certain powers of public authorities [10].

Some tend to distinguish two types of decentralization - the administrative (or bureaucratic) and the democratic. The administrative decentralization stands for an extension of the competence for local administration, allowing a certain degree of independence from central government. The democratic decentralization provides for the establishment of a ramified local government system, when all the local matters are decided by the locally elected officials rather than central government representatives [5].

Referring to studies made by the Faguet J-P., O. Nizhnik distinguishes a number of types for decentralization process, including political, administrative, fiscal and market decentralization - all of them tend to take a variety of forms. The political (or democratic) decentralization provides for a transfer of authorities to elected officials representing a certain administrative unit (to local government) that involves the right to levy some of the taxes (including their rates, to a certain extent) and make decisions on their spending. One of the extremities of this type may involve the transfer of so much authorities and resources to a local government that precludes any further public transfers. According to a number of scientists, this may produce an increase in their responsibility for rendering public services and promote the legitimacy of actions taken by local politicians. Ukraine is currently opting for a similar type of massive political decentralization that involves the implementation of its fiscal (or budgetary) form and a corresponding increase of local budgets by expanding the right of territorial communities to levy taxes [15].

The notion of democracy on the other hand has a variety of interpretations and theories that offer a different importance to a decentralization process. According to Robert Dahl's theory of polyarchal democracy, the decentralization of public authority should not be considered a necessary precondition for democracy. On the contrary, the decentralized public authority plays a significant role in two of the most popular theories of democracy (liberal and participatory) in terms of its practical application. Although, those theories have different approach to the substantiation of this role. The theorists of liberal democracy see decentralization as a tool to limit the influence of central government on the society and economic life (Bolick, 1995). Whereas, the theory of participatory democracy believes that decentralization could be used to promote the political commitment of citizens at a local level. 
This theory criticizes the liberal democracy for reducing the political commitment at a local level.

According to M. Kornienko, a truly democratic nation cannot dispense with the decentralization of its executive power. In the same time, the most serious challenge comes with the substitution of notions. This is when the notion of decentralization is used without reference to its type (democratic (devolution) or administrative decentralization, which provides for the establishment of specific governmental bodies (local state administrations, prefectures, government commissioners, etc.) representing the so-called vertical chain of the government or executive power) that results in attributing the pseudo- or quasi-characteristics to a decentralization at the application (rule-making) level [7].

The decentralization may be clearly considered as a form of developing the democracy, which allows to preserve the unity of the state and its institutions, while expending local governance, promoting the commitment of citizens to support their needs and interests, limiting the sphere of influence of the State over the society (replaced with the mechanism for self-governance as developed by the society), and reducing the civil service costs covered by the nation and tax-payer's money [21].

International experience All research papers on decentralization admit the absence of a unified (universal) approach to decentralization, including its components, types and models, both in theory and in practice. The selection of forms and priorities for decentralization is all about the formulation of national strategy for cooperation between the organization of public authority and administration at all levels of territorial arrangement.

According to analysis of decentralization reforms and their impact on increasing the role and development of local government in foreign countries, the current local government systems along with the administrative and territorial structure of European countries resulted from the development of national states under conditions of democratization, urbanization, introduction of legal checks and balances system as well as in response to the needs of the modern society, the spread of the movement for social control and attempts to establish a welfare state.

The changes in the system of government may be roughly divided into the following types: changing the number of administrative units, institutional reforms, financial reforms, functional reforms and procedural reforms [11]. 
The first wave of reforms in European countries was marked by a reduction of administrative units to include municipalities. It was often assumed that effective and efficient rendering of services locally would require a larger constituency and administrative unit [16].

This perception was certainly widespread by the Nordic Countries and the Great Britain. Similar reforms took place in Sweden, Denmark and Finland. The municipalities of Sweden converged around the neighbouring cities to facilitate the performance of joint functions that was incorporated into their legislation.

The consolidation of communities in different European countries resulted in both positive and negative consequences (primarily in France). Since most of the successes occurred in case of voluntary consolidation of municipalities, this type of changes should be taken as the basis for territorial reforms in Ukraine [23].

The development of regional democracy and self-government in European countries were the other important areas for reforms. The intermediary level of governance was reinforced to settle challenges of ever-growing urbanization and the demand for new types of services. It allowed to take decisions and operate throughout an area that exceeded a single municipality (community) and served an effective tool for territorial and spatial planning, etc. [17].

The movement in support of decentralization / democracy in Spain and Italy, joined by Norway, Denmark, Germany and France after World War II, was yet another factor that promoted an intermediary level of governance at the regional level.

This process finally led to a development of three levels of governance: national, intermediary (regional) and local. The intermediary level of structures was represented with fairly new regional elected authorities entrusted with executive and, to a certain extent, legislative powers (Belgium, Germany, Spain, Portugal, Italy).

The other type of reforms that took place in Europe in the end of XX century were institutional reforms. They were only possible in case of a strong influence of central authority and provided for organizational changes within territorial units that involved the following aspects: strengthening of the role of mayors and elected councils; increasing the openness, transparency and democratic nature of the decision-making process; strengthening the role of public in the decision-making process; introducing compulsory planning mechanisms (for "efficient planning"); replacing local staff and amending regulations on the activity of 
authorities. Those activities were primarily designed to promote the commitment of local government within the political system of a corresponding country and turn them into main public policy advocates (Italy, Great Britain, etc.).

Most of the recent decentralization reforms in European countries brought an increase in the amount of resources for local government [18].

The functional and procedural reform included a range of activities designed to decentralize the power of public authorities by delegating it to local government. In Great Britain, the responsibility for rendering social services was entrusted upon local level to make it closer to ordinary people. Italy decided on similar decentralization efforts covering most of the state functions.

In some countries (France, Italy, Spain), the prefects lost much or all of their oversight function in relation to local government. It was accompanied with the introduction of new systems for planning and raising the efficiency of rendering services (Germany, France, Denmark).

The following major objectives of decentralization reforms could be identified for most of European countries: higher quality of services for population, greater effectiveness of public authorities and local government, services closer to the people (introduction of the subsidiarity principle), transparent public administration, higher commitment of citizens to a decisionmaking process, consolidated budgetary polity, more resources for local government [22].

The public administration reform in Central and Eastern Europe (particularly Poland, Hungary, the Czech Republic, Slovakia, and Baltic states) in the period from the late 1980s to the early 1990s was largely determined by strategic objectives of corresponding countries and their European integration policy. Some of the main directions of this reform included the use of many forms of decentralization (primarily the establishment of the municipal level), the introduction of subsidiarity principle and bringing the administration system in line with the EU standards [14].

The current stage of reforms in public administration of the EU countries with decentralization in mind is based on the following principles: development of civil society, effectiveness, transparency, openness and accountability of public authorities, flexibility and subsidiarity. These principles define the whole modern European paradigm of public 
administration within the EU (so-called "good governance system"), which is applied at all levels of administration: Pan-European, national, regional and local [9].

The situation in Poland proves that decentralization could be successful if combined with other democratic reforms. The dissolution of the socialist bloc was followed by the restoration of multi-party system, media pluralism and conditions the development of civil society (Kaldor 1997). This sort of decentralization has demonstrated positive results and became one of the models to consider while developing reforms in Ukraine. Most notably, the introduction of fiscal decentralization reduced the deficit of local budgets (Bukowska, Siwińska-Gorzelak 2018). More authorities for voivodeship allowed for a direct EU funding, which could be around $30 \%$ of their receipts [12].

The decentralization is a complex, comprehensive and extremely difficult process, which is considered one of the major principles for organization and operation of public authority, the strategic direction for modern national policies, and a component of the most sector reforms.

Under current environment, decentralization is considered a factor of political security that becomes ever more important and controversial today. The priority and strategic importance of the decentralization principle in the national policy is unquestionable, both within the international and national domains. It can be seen in the provisions of key regulations of institutional and legal nature that outline the national policy of Ukraine, particularly the Association Agreement between the European Union, European Atomic Energy Community and its Member States, of the one part, and Ukraine, of the other part, the Strategy on Sustainable Development "Ukraine - 2020", the Coalition Agreement, the Action Program of the Cabinet of Ministers of Ukraine, and the Medium-Term Government Priority Action Plan up to 2020. These documents reflect the intentions of the country and the willingness of its society to modernize their public administration system and have its components brought in line with international legal standards.

Greater political commitment among the primary power entities (citizens and community) is vitally important and needed.

An important constituent element of public authority is the mutual responsibility of both local authority or government and territorial communities. It places special responsibility on 
the institution of civil oversight, whose procedures, even if imperfect, are mentioned on the constitutional and legislative level [20].

Peculiarities of reform in Ukraine A substantive political dialogue between Ukraine and the Congress of Local and Regional Authorities of the Council of Europe took place in 2013 to promote the implementation of its Recommendations 348 (2013) on the local and regional democracy in Ukraine in accordance with the Resolution 353 (2013) REV "On Congress post-monitoring and post-observation of elections: developing political dialogue". It was followed by the development of the Post-Monitoring Programme (PMP) with three postmonitoring units (PMU) based on major recommendations (REC 348 (2013)) for authorities designed upon the results of their missions in 2012 and 2013: 1. Clause 7d-on the transfer of authority; 2. Clause $7 \mathrm{c}-$ on the financial independence; 3 . Clause $7 \mathrm{a}-$ on the incorporation of territorial units and cooperation between municipalities.

The reform was started under extremely difficult circumstances of having a foreign aggression and domestic instability.

The decentralization reform was started in April 2014 with the approval of the concept of reforming the local self-government and territorial organization of power by the Government of Ukraine.

The results of monthly monitoring by the Ministry of Regional Development are posted on the official website for decentralization efforts. The decentralization and reform of local self-government in Ukraine are characterized by the following indicators.

The achievements of decentralization process The legal framework of reforms was developed in compliance with the Constitution. It included over 30 laws and other regulations designed to promote its implementation. The laws of Ukraine on voluntary association of territorial communities and their cooperation laid the foundations for another stage of administrative decentralization that involves the establishment of capable (basic) local government - the Associated Territorial Communities (ATC). A total of 865 ATCs (see Fig. 1) were established as of November 2018, to include 3981 (see Fig. 2) associations of village, settlement and city councils on voluntary basis (7.1 million people or $20 \%$ of the total population of Ukraine). 


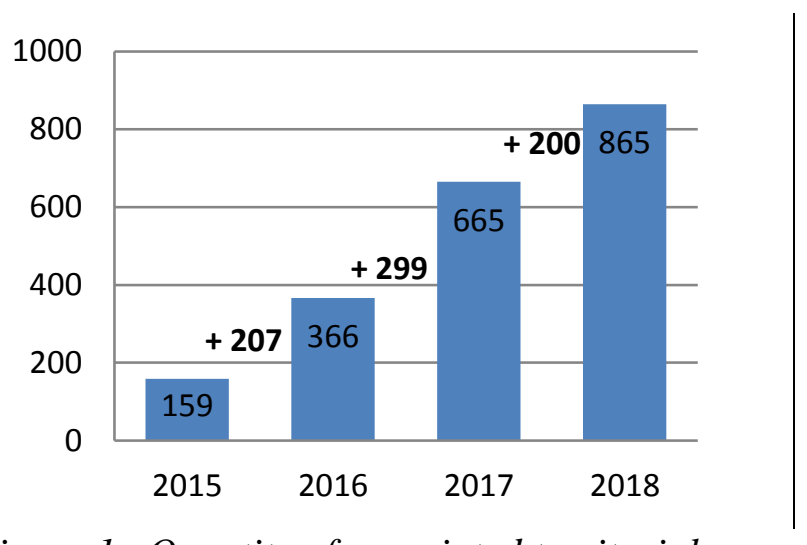

in 2015 - 2018

865 associated territorial communities (705 communities - first local elections took place, 123 communities - first elections are scheduled for 23.12.2018, 21 communities - pending the decisions of the Central Electoral C

Figure 1. Quantity of associated territorial communities

Source: Data on monthly monitoring of the process of decentralization in Ukraine https://decentralization.gov.ua/about
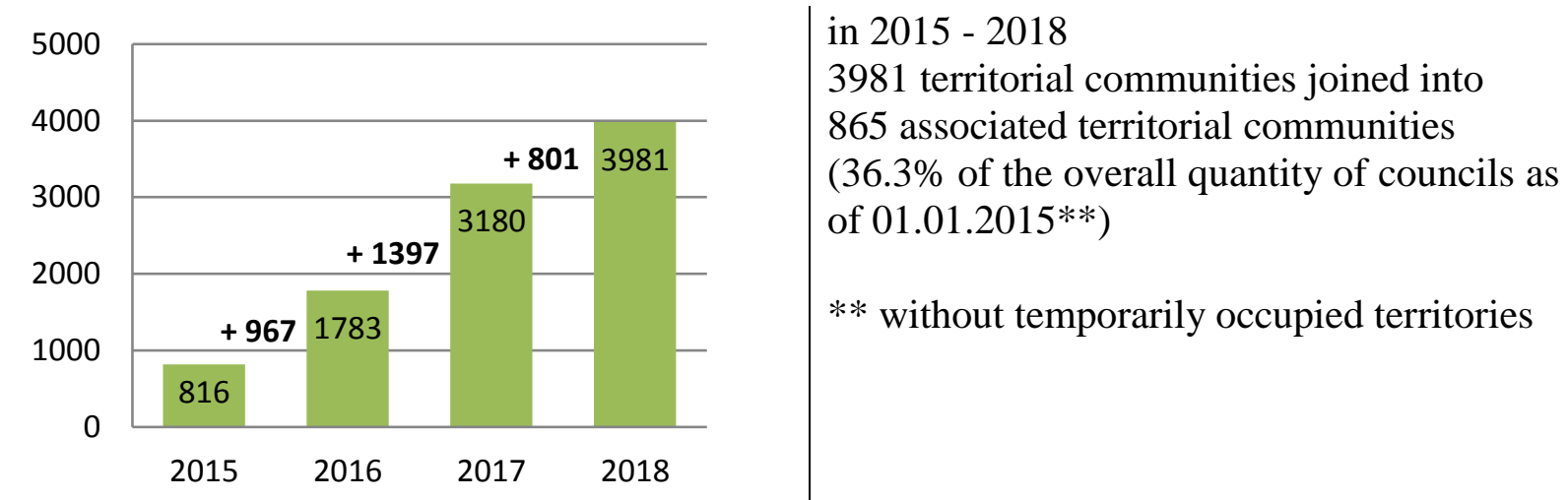

Figure 2. Quantity of territorial communities to join the Associated Territorial Communities Source: Data on monthly monitoring of the process of decentralization in Ukraine https://decentralization.gov.ua/about

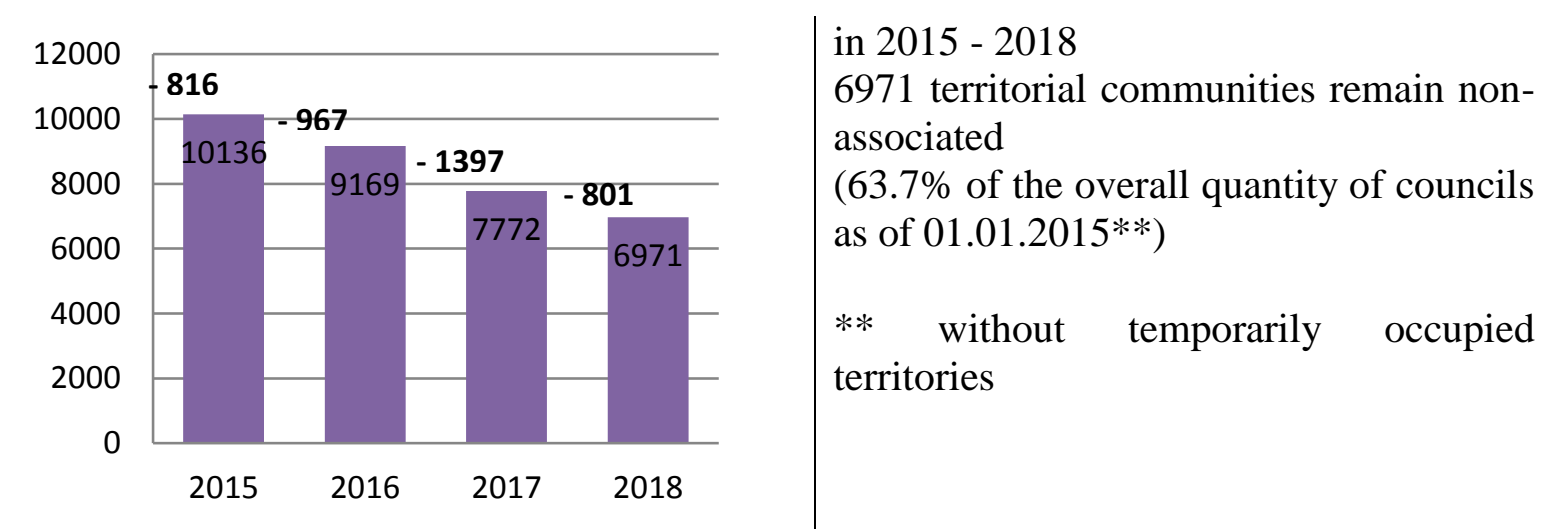

Figure 3. Quantity of non-associated territorial communities

Source: Data on monthly monitoring of the process of decentralization in Ukraine https://decentralization.gov.ua/about

The introduction of amendments to the Budget and Tax Codes of Ukraine produced an increase in budgets of local government from 68.6 billion UAH in 2014 to around 231 billion UAH in 
2018 (increase by 3.4 times). The largest growth rate of incomes is demonstrated by ATCs with direct inter-budgetary relations to the national budget, unlike the rest of local governments. When compared to 2017, their income increases for 2018 was $62 \%$, while the rest of the local budgets had an increase by $22 \%$. The state is actively supporting the decentralization reform of public authority to use it as a foundation for public administration reform. When compared to 2014, the government support to the development of territorial communities and their infrastructure has increased by 39 times and currently amounts to 37.8 billion UAH (see Fig. 4).

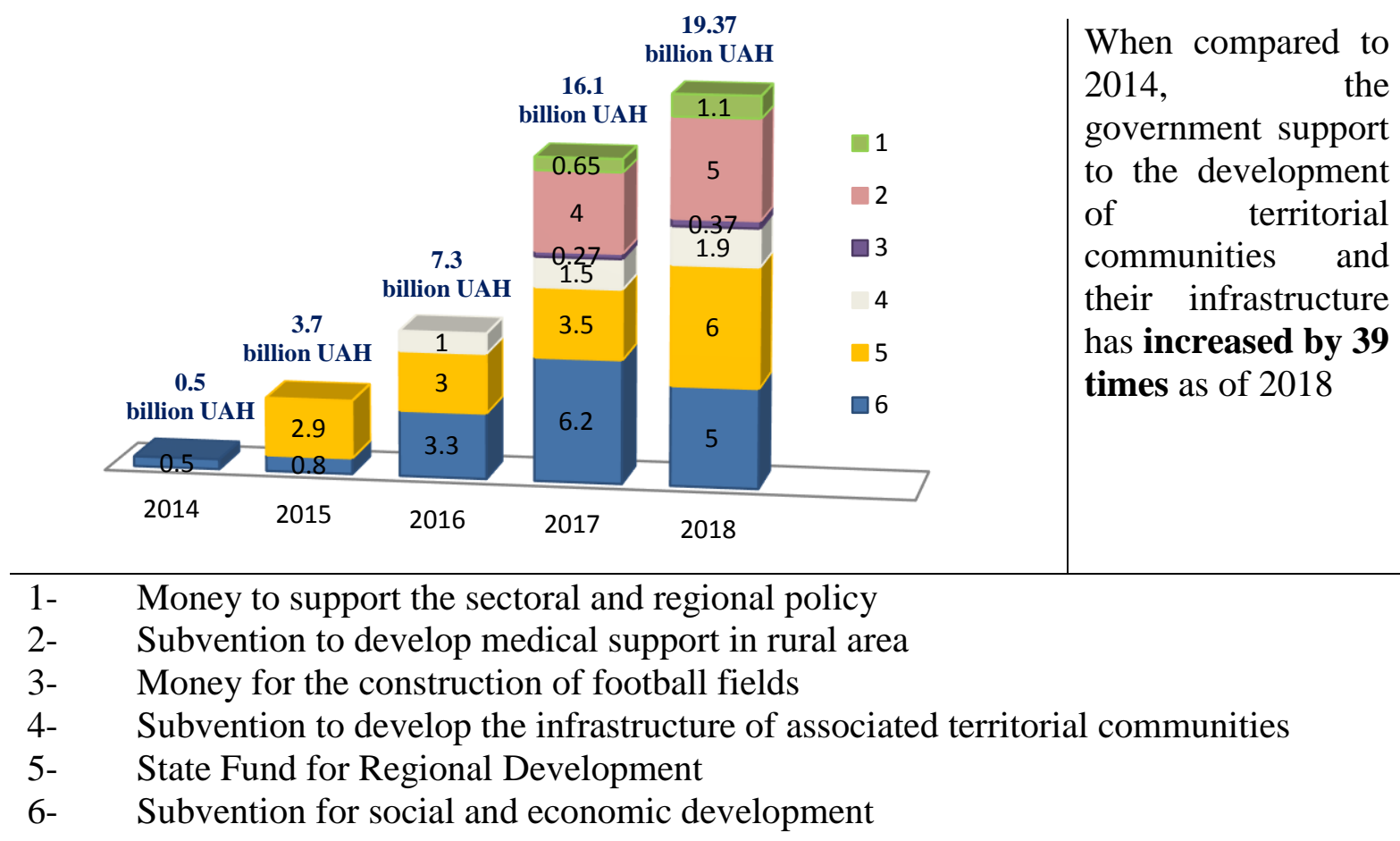

Figure 4. Support to the development of territorial communities and their infrastructure by the government

Source: Data on monthly monitoring of the process of decentralization in Ukraine https://decentralization.gov.ua/about 


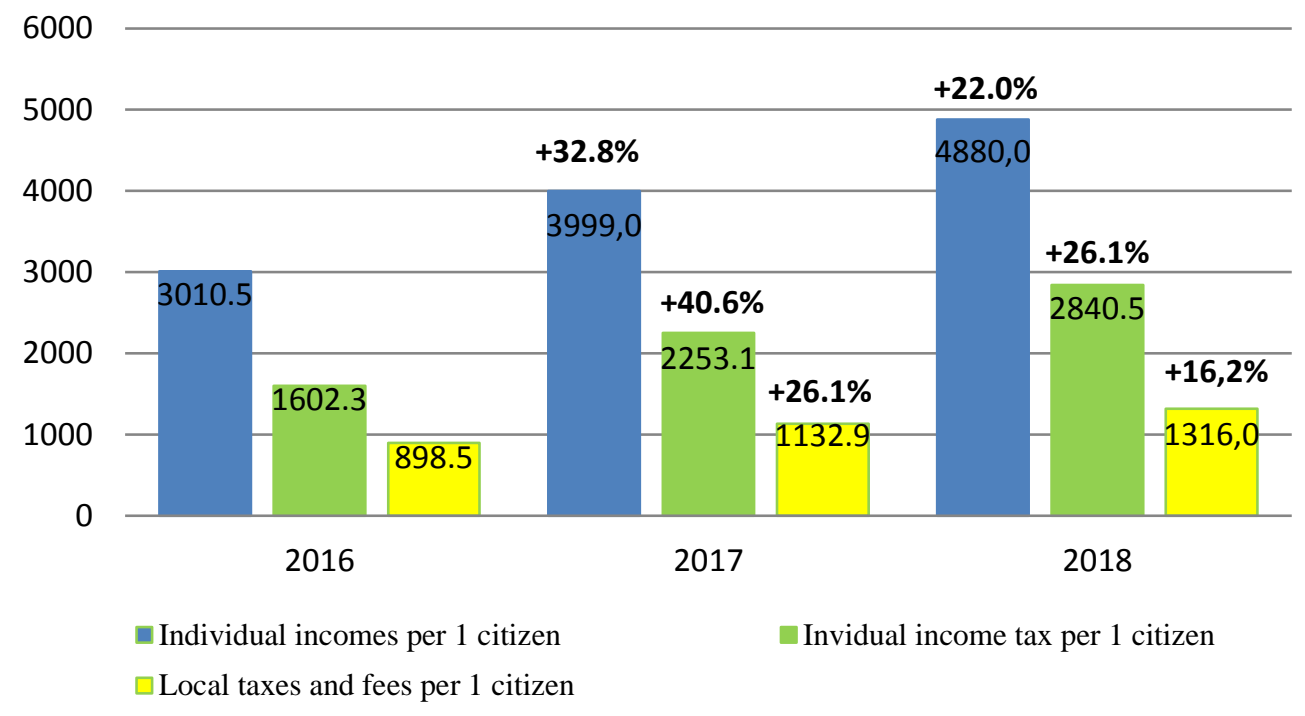

Figure 5. Impact of financial decentralization on the increase of local budgets (2016-2018) Source: Data on monthly monitoring of the process of decentralization in Ukraine https://decentralization.gov.ua/about

The position of a headman was officially established. This person is elected by the population of village(s) or town(s) located within the corresponding headman's district based on universal, direct, equal and universal suffrage and a secret ballot as provided by the law. The headman exercises its authority on a permanent basis.

The services were brought closer to the consumers with the establishment of centres for the provision of administrative services. A total of 775 centres have been established so far (see Fig. 6). This includes 452 centres established by local state administrations and 103 centres established by the associated territorial communities.
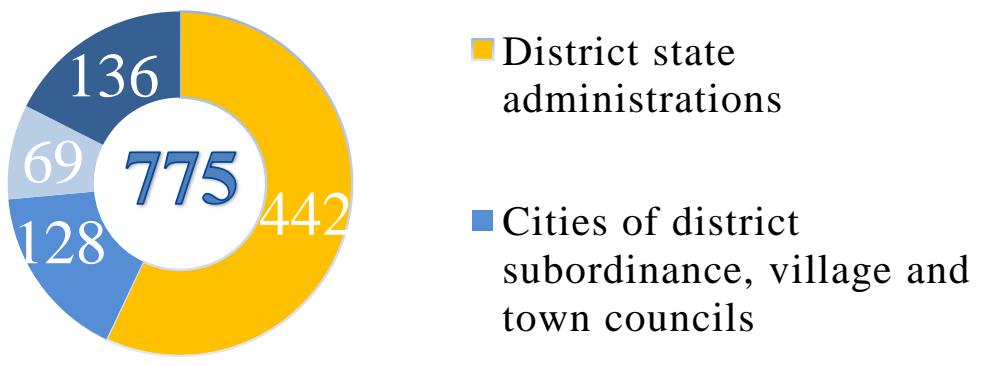

Figure 6. Distribution of centres for the provision of administrative services by the originating agencies

Source: Data on monthly monitoring of the process of decentralization in Ukraine https://decentralization.gov.ua/about 
The decentralization (transfer of power from central executive authorities to local government) has been implemented in the following areas: education; health care; social policy; as well as architectural and construction supervision; administrative services (approval documents, registration of place of residence, entrepreneurs, real estate, extracts from the state land cadastre); local taxation (rates and benefits) since the authority to determine the minimum rent on land was delegated in 2017; procedure for imposing local taxes and fees was simplified; any offenses in the field of labour and employment (since 2017) are carefully monitored; banking services (own incomes of budgetary institutions and development budgets); direct appointment of accountants for budgetary institutions (all candidates should be agreed by the treasury before 2015); remaining subventions on education and medical support should be directed on the development of material and technical support for institutions.

The conditions were established to promote the cooperation among the non-associated territorial communities. The legal framework supporting the rights of local government to municipal consolidation; cooperation of financial, institutional and other resources; establishment of joint public utilities and their administration resulted in concluding 274 agreements with 1096 local councils.

The powers and resources allocated to local government as a result of decentralization provided additional capabilities for territorial development and support of modern education, health care, transport, as well as housing and utilities infrastructure.

The local authorities became more interested in promoting the investment attractiveness of their region for the benefit of the community, since all the collected taxes will be allocated for improving the life quality of its residents. A range of permits and approval documents for business activity can be obtained locally, while the community itself is able to attract investments to support the social and economic development.

The associated territorial communities can already feel the benefits of the reform as they observe the repair of the roads in villages, towns and cities as well as the construction of water pipelines and refurbishment of medical and educational facilities - that remained in decline for over a decade. 
The reform promoted a comprehensive development of the community, allowing to increase the quality of life in every single settlement and the country as a whole, since all citizens were given a chance to rule where they live.

Risks of decentralization The concept of local self-government reform in Ukraine considers building a new territorial organization of public authority as an important component of the process. That is creating an administrative and territorial structure capable of becoming the foundation for modern public administration.

According to V. Nehoda (2018), the establishment of new joint communities proceeds at a steady rate. More communities are joining the cities with provincial status or associated territorial communities. These communities receive most of authorities and financial resources. In other words, the local self-governments are being established at the most capable communities (in addition to regional councils and regional state administrations) and serve as independent entities on a district basis. In this case, the functions and authorities of a district remain legally unchanged together with the standing division into districts. This results in conflicts of law and political conflicts between the three subjects of public authority, which are different by their origin. Hence, new challenges appear in the administration and complex socio-economic development of district territories.

The practical transformation of basic administrative and territorial units produced a need for further reform of local government, territorial organization of power, administrative and territorial structure, and consolidation of districts at a sub-regional level. This process is currently impeded by a number of village councils, still working on approval of plans for territorial establishment of regional communities.

New territorial framework should be established at the level of communities and districts before the local elections in 2020. Otherwise, the decentralization, which is all about the clear division of powers, budgets, and responsibilities between the authorities and self-government as well as between the levels of local governance, would be doomed to a standstill. The communities should not depend on the inability, lack of desire and political or other interests of the regional council. There is a need for clear guidelines on the establishment of administrative and territorial structure (draft law registered in the Verkhovna Rada of Ukraine under No. 8051) followed by 24 separate laws (or one overarching document) on the administrative and territorial structure of every region [29]. 
According to O. Nyzhnyk, the decentralization process comes with many risks and challenges, including those of a scientific and methodological nature. The main obstacle in terms of its implementation would be the absence of a comprehensive approach to public administration reform coupled with fragmentary performance and incompleteness of other important reforms (judicial, budgetary, tax, institutional, administrative and territorial, social, educational, and medical) [15].

There are many challenges, risks and obstacles with the decentralization of power when it goes to transferring authority to local government. Although, as confirmed by O. Skrypniuk, "there is no alternative to decentralization, since its success may serve a pre-requisite for effective territorial development and true people's power in Ukraine" [11].

Conclusions The implementation of local government reform and decentralization of power in Ukraine should result in a development of new democratic model of governance that follows the devolution principles. It should promote the role of territorial communities entrusted with greater power and authority along with financial and material resources at the cost of personal responsibility attached. The implementation of decentralized processes should cover many spheres of social life, including the economy, health care, education, and social support. All these may promote the consistency and coordination of reform efforts.

The decentralization of power in Ukraine increases the commitment of Ukrainian citizens to national administration; brings the public and administrative services closer to their consumers at a local level; educates the feeling of community and involvement into local decision-making process; promotes the balance between the public and social interests; forms a precondition of effective public authority and strengthening of democracy.

Ukraine took a difficult and complex path of development. In the same time, it faces a historic moment when all the reforms, however selective and attributive they were in the past, may be implemented in present.

\section{References}

[1] Averianov, V. (1998). Public administration: theory and practice. Challenges in transformation of the territorial organization of power /under the editorship of $\mathrm{M}$. Pukhtynskyi. (2005), 852. 
[2] Congress of Local and Regional Authorities of the Council of Europe Continues Cooperation with Ukraine in the Issues of Local Self-Government Reform (2015). Retrieved from: https://decentralization.gov.ua/news/335

[3] Encyclopedia of Public Administration: 8 volumes (2011). National Academy of Public Administration under the President of Ukraine.

[4] Hamburg, L. (2014). Theory behind the decentralization of governmental authority in a public authority system of unitary state. Bulletin of Zaporizhzhia National University, 4 (I), 134-145.

[5] Hladka T. (2015). Decentralization of power in Ukraine as a tool for strengthening democracy and increasing stability. "Public administration: improvement and development" Retrieved from: http://www.dy.nayka.com.ua/?op=1\&z=937

[6] Kofanov, A.V. (2006). Judicial expertise as one of the types of protection of production and other constitutional rights and freedoms of Ukrainian citizens. Elections-2006: Experience. Problems. Perspectives: a collection of materials of the international scientific and practical conference, 293-301.

[7] Kornienko, M. (2006). Statutory and legal framework for local government. Municipal law of Ukraine, 146-148.

[8] Kovbasiuk, Y., Vashchenko, K. \& Tolkovano V. (2014). Local government in Ukraine: current state and main guidelines for modernization: scientific paper, 128.

[9] Kresina, I., Kovalenko, A. \& Vitman, K. (2009). Administrative and territorial reform in Ukraine: political and legal problems, 480.

[10] Kuchynskyi, O. (2018) The impact of decentralization on democratic transition. Journal of Social Criticism "Common". Retrieved from:

https://commons.com.ua/ru/decentralizatsia-i-demokratyzatsia/

[11] Kuibida, V., Ischenko, O., Tkachuk, A. \& Tolkovanov V. (2009). New state regional policy, 232.

[12] Kudłacz, T. \& Markowski, T. (2018). The territorial capital of urban functional areas as a challenge for regional development policy: An outline of the concept. Public Governance, (44), 2. https://doi.org/10.15678/ZP.2018.44.2.03

[13] Monitoring - Decentralization of power- Access mode: $\underline{\text { https://decentralization.gov.ua/\% }}$

[14] Nyzhnyk, N. (1997). Public administration in Ukraine: centralization and decentralization, 448.

[15] Nyzhnyk, O. (2016). Theoretical Aspects of the Impact of Decentralization on the Development of the State and Territorial Communities. Bulletin of the National Academy of Public Administration under the President of Ukraine. Series: Public administration. (3), 56-62. Retrieved from: http://nbuv.gov.ua/UJRN/vnaddy_2016_3_10

[15] Odintsova, H., Mostovyi, H. \& Amosov, O. (2002). Public administration and management: textbook with tables and diagrams, 492.

[16] Pukhtynskyi, M. \& Tolkovanov, V. (2003). European Charter of Local Self-Government and Development of Local and Regional Democracy in Ukraine, 400. 
[17] Pukhtynskyi, M. (2006). Challenges of decentralization: foreign and national experience, 744.

[18] Pukhtynskyi, M. (2009). European benchmarks for local and regional development, 508.

[19] Pukhtynskyi, M. Decentralization principles of public authority. (2015). Scientific library (12), Retrieved from: http://veche.kiev.ua/journal/4782/

[20] Pryhodko, V. (2012). Decentralization of public administration and local government: conceptual and legal issues, 91-101.

[21] Skrypnuik, O. (2015). Decentralization of power in support of stable constitutional order: theory and practice. Viche: socio-political and theoretical journal. (12), 22-24.

[22] Tolkovanov, V. (2007). Legal instruments of the Council of Europe concerning the local and regional development and challenges of their implementation in Ukraine, 349.

[23] Tolkovanov, V. (2011). Development of municipal cooperation: foreign and national experience, 249.

[24] Tworek, P. (2018). Risk management in a municipal construction enterprise: A theoretical and methodical study. Public Governance, (44), 2. https://doi.org/10.15678/ZP.2018.44.2.06

[25] The outcomes of post-monitoring in Ukraine (2015). Retrieved from: https://www.eurointegration.com.ua/files/a/b/abcf6ba-mfa.pdf

[26] Varnalii, Z. (2007). State regional policy of Ukraine: peculiarities and strategic priorities, 768.

[27] Varnalii, Z. (2007). State regional policy of Ukraine: peculiarities and strategic priorities, 820. Retrieved from:

[28] Waasowicz, K.(2018). Assessment of the efficiency of municipal companies based on local collective transport. Public Governance, (44), 2. https://doi.org/10.15678/ZP.2018.44.2.04

[29] What is Decentralization. Retrieved from: www.worldbank.org 